\title{
Mekanisme Pembayaran Royalti Lagu dan Musik Dalam Aplikasi Streaming Musik
}

\author{
Muh. Habibi Akbar Rusly ${ }^{1}$, Mukti Fajar ND² \\ ${ }^{1,2}$ Program Studi Hukum, Fakultas Hukum, Universitas Muhammadiyah Yogyakarta, Indonesia \\ Jl. Brawijaya, Tamantiro, Kasihan, Bantul, Yogyakarta \\ E-mail: ${ }^{1}$ muh.habibi.2012@law.umy.ac.id; ${ }^{2}$ muktifajar_umy@yahoo.co.id
}

\section{Info Artikel}

Diajukan: 22-02-2020

Direview: 17-03-2020

Direvisi: $30-03-2020$

Diterima: 01-04-2020

DOI: $10.18196 / \mathrm{mls} . v 1 i 2.8344$

\section{Abstrak}

Kemajuan teknologi memiliki dampak positif maupun negatif bagi setiap lini kehidupan. Dampak positif yang didapatkan adalah kemudahan setiap orang dalam berkarya bisa dengan mudahnya dipublikasikan ke khalayak umum, sementara dampak negatif yang didapatkan adalah terkadang masih banyak orang tidak mengetahui adanya peraturan mengenai Hak Cipta. Berkaitan dengan hal tersebut, masalah ini menunjukkan bahwa problematika terkait pelanggaran Hak Cipta terus terjadi, dimana perkembangan teknologi dimanfaatkan oleh berbagai pihak yang tidak bertanggung jawab untuk mencari keuntungan pribadi dengan mengabaikan Hak Cipta yang dimiliki individual tertentu yang dapat berdampak mematikan kreasi para Pencipta karena peredaran lagu yang dulunya terbatas baik jumlah dan keasliannya, tetapi sekarang ini batasan-batasan tersebut terhapus dan peredarannya tidak dapat dibatasi baik secara jumlahnya dan keaslian daripada lagu yang beredar. Metode yang digunakan adalah penelitian hukum normatif yaitu penelitian hukum yang menggunakan bahan hukum primer, bahan hukum sekunder, dan bahan hukum tersier yang diperoleh melalui bahan-bahan kepustakaan dan dilengkapi dengan melakukan wawancara kepada Digital Publisher sebagai pengelola hak cipta bagi pemegang hak cipta musik atau lagu. Perlindungan Hukum Terhadap Pencipta atas Pembayaran Royalti Lagu dan Musik dalam aplikasi streaming musik telah dilakukan melalui berbagai kebijakan yang dibuat oleh penyedia layanan streaming musik.

Kata kunci: hak cipta, streaming musik, royalti.

\section{Pendahuluan.}

Saat ini mendengarkan musik bisa dibilang menjadi salah satu sarana untuk menghilangkan kebosanan maupun menunjang aktivitas dalam kondisi tertentu. Smartphone menjadi salah satu sarana pilihan terbaik untuk mendengarkan musik karena selain sangat efektif juga sangat efisien untuk penggunaannya. Agar bisa mendengarkan lagu yang diinginkan beberapa orang mungkin akan membeli lagu tersebut secara digital, tidak sedikit juga yang mengunduhnya secara illegal downloading diberbagai situs website karena memiliki keuntungan yaitu gratis dan akses yang sangat mudah.

Semua perusahaan berlomba menciptakan layanan streaming musik karena potensi bisnis streaming musik terlihat sangat menjanjikan. Beberapa aplikasi streaming musik yang masih eksis atau bisa dibilang penggunanya masih banyak yaitu Joox 
Music, SoundCloud, Spotify, Musixmatch. Salah satunya ada Spotify, yang akhir-akhir ini penggunanya terus meningkat. Spotify merupakan aplikasi streaming musik yang ada di iOS/Android. Platform populer seperti Spotify juga menjadi salah satu aplikasi streaming musik terbesar, dengan memiliki lebih dari 30 juta lagu untuk diputar dan lebih dari 70 juta pelanggan. Selain itu aplikasi ini juga merupakan satu-satunya pesaing terbesar dari Apple Music. Aplikasi Spotify ini juga menawarkan banyak sekali lagu yang up to date dan sangat lengkap. Aplikasi ini memiliki desain serta fitur yang sederhana sehingga memudahkan para penggunanya dalam menggunakan aplikasi ini. ${ }^{1}$

Munculnya berbagai aplikasi musik streaming yang menyediakan ribuan bahkan jutaan lagu dari berbagai penjuru dunia secara bersamaan dapat menimbulkan masalah hukum terkait pelanggaran Hak Cipta. Hal ini dikarenakan pertumbuhan perusahaan penyedia layanan streaming musik yang begitu pesat tidak diimbangi dengan sistem pengawasan yang baik. Semakin hari, semakin banyak karya-karya yang terus diciptakan oleh manusia, baik itu dalam bidang industri, teknologi dan tidak terkecuali dalam bidang seni seperti tari sastra, film, dan musik baik itu dalam format mp3 atau mp4. Dengan bertambahnya karya-karya tersebut, manusia menyadari akan adanya hak baru di luar hak kebendaan atau barang. Pengakuaan atas segala temuan, seperti ciptaan dan kreasi baru yang ditemukan dan diciptakan baik oleh individu maupun kelompok telah melahirkan apa yang disebut dengan Hak Kekayaan Intelektual (HKI).

Dalam rangka pengeksploitasian Hak Cipta, seorang Pencipta tidak dapat melaksanakan sendiri secara maksimal tanpa ada bantuan dari organisasi Hak Cipta yang secara khusus menangani masalah tersebut, terutama untuk ciptaan musik atau lagu. Para Pencipta atau Pemegang Hak Cipta tidak mungkin mendatangi setiap penyelenggaraan acara musik satu persatu, seperti konser, televisi, radio, hotel, karaoke, klub malam, dan lain-lain untuk menagih hak ekonominya. Di Indonesia tugas tersebut dijalankan oleh salah satu Lembaga Manajemen Kolektif yaitu Yayasan Karya Cipta Indonesia (YKCI) yang melaksanakan pengadministrasian kolektif atas pemakaian Hak Cipta dari para Pencipta lagu atau musik, baik ciptaan Indonesia maupun asing. ${ }^{2}$

Undang-Undang Hak Cipta mengatur hak apa saja yang dimiliki oleh seseorang, kapan Hak Cipta tersebut terjadi, ciptaan apa saja yang dilindungi dalam Hak Cipta, perlindungan apa saja yang didapatkan Pencipta atau Pemegang Hak Cipta serta konsekuensi yang didapat bagi setiap orang yang melanggar Hak Cipta. Ada juga sistem yang mengatur pembayaran royalti, setiap lagu dihitung berapa kali diputar dalam sebulan, setiap tempat usaha wajib memasang mesin maupun perangkat lunak yang menghitung berapa kali suatu lagu diputar selama sebulan guna memudahkan penyelidikan.

\footnotetext{
${ }^{1}$ Deliusno, 2016, Spotify Masuk, Total Ada 8 Layanan “Streaming” Musik di Indonesia, https://tekno.kompas.com/read/2016/03/31/13140017/Spotify.Masuk.Total.Ada.8.Layanan.Stre aming.Musik.di.Indonesia?page=all, di akses pada tanggal 13 Oktober 2019 pukul 10.04 WIB

${ }^{2}$ Karya Cipta Indonesia, 2018, Karya Cipta Indonesia (KCI) adalah Lembaga Manajemen Kolektif (LMK) hak cipta lagu, http://kci-lmk.or.id/, di akses pada tanggal 8 April 2019 pukul 10.43 WIB
} 
Pelanggaraan Hak Cipta atas sebuah lagu pada aplikasi musik terjadi pada tahun 2017 silam yang dilakukan Hanin Dhiya Citaningtyas yang melakukan remake (aransemen ulang) terhadap lagu dari grup band Payung Teduh. Berangkat dari remake (aransemen ulang) lagu tersebut kemudian Hanin Dhiya tertarik untuk menjual suara merdunya pada aplikasi musik Spotify dan i-tunes tanpa seizin management Payung Teduh. Hal tersebut menunjukan masih terdapat kelemahan dalam perlindungan hukum yang dalam kebijakan penyebaran Hak Cipta yang diberikan oleh aplikasi streaming musik Spotify. ${ }^{3}$ Selain itu, berdasarkan beberapa pemberitaan, penulis telah meneliti dan menemukan setidaknya sejak tahun 2015 sampai 2018 Spotify sendiri telah mengalami beberapa kali tuntutan terkait pelanggaran Hak Cipta, misalnya pada tanggal 31 Desember 2015 musisi David Lowrey mengajukan tuntutan terhadap Spotify yang tidak memberikan royalti dalam mendistribusikan musik yang telah memiliki Hak Cipta. ${ }^{4}$ Selain itu, Spotify pada tanggal 03 Januari 2018 mendapat tuntutan dari Wixen Music Publishing sebesar 21,6 trilliun atas penggunaan ribuan lagu yang memiliki Hak Cipta. ${ }^{5}$

Dari pemaparan kasus tersebut dapat diketahui bahwa kemajuan teknologi dapat saja membuat dampak positif maupun negatif. Dampak positif yang didapatkan adalah kemudahan setiap orang dalam berkarya bisa dengan mudahnya dipublikasikan ke khalayak umum, sementara dampak negatif yang didapatkan adalah terkadang masih banyak orang tidak mengetahui adanya peraturan mengenai Hak Cipta.

Berkaitan dengan hal tersebut, masalah ini menunjukkan bahwa problematika terkait pelanggaran Hak Cipta terus terjadi. Perkembangan teknologi dimanfaatkan oleh berbagai pihak yang tidak bertanggung jawab untuk mencari keuntungan pribadi dengan mengabaikan Hak Cipta yang dimiliki individual. Halini dapat berdampak mematikan kreasi para Pencipta karena peredaran lagu yang dulunya terbatas baik jumlah dan keasliannya, tetapi sekarang ini batasan-batasan tersebut terhapus dan peredarannya tidak dapat dibatasi baik secara jumlahnya dan keaslian daripada lagu yang beredar. Padapenelitian ini lebih menekankan pembahasan terkait mekanisme Pembayaran Royalti atas Lagu dan Musik dalam aplikasi streaming musik kepada Pencipta

\section{Metode Penelitian}

Metode penelitian yang digunakan yaitu penelitian normatif (legal research), jenis penelitian ini digunakan untuk meneliti bagaimana perlindungan hukum terhadap

\footnotetext{
${ }^{3}$ Anita Wardani, 2017, Vokalis Payung Teduh Kecewa dengan Hanin Dhiya Gara-gara Cover Lagu Akad, https://www.tribunnews.com/seleb/2017/10/03/vokalis-payung-teduh-kecewa-dengan-hanin-dhiyagara-gara-cover-lagu-akad, di akses pada tanggal 3 Desember 2019 pukul 20.59 WIB

${ }^{4}$ Mochamad Wahyu Hidayat, 2015, Dianggap Curangi Artis, Spotify Dituntut US\$150 Juta, https://www.liputan6.com/tekno/read/2400645/dianggap-curangi-artis-Spotify-dituntut-us-150-juta, di akses pada tanggal 8 April 2019 pukul 20.00 WIB

${ }^{5}$ Kustin Ayuwuragil, 2018, Spotify Dituntut Triliunan Rupiah Oleh Label Musik, https://www.cnnindonesia.com/teknologi/20180103152623-185-266437/Spotify-dituntut-triliunanrupiah-oleh-label-musik, di akses pada tanggal 8 April 2019 pukul 20.09 WIB
} 
pencipta atas ciptaannya yaitu lagu atau musik dalam aplikasi streaming musik. Penelitian hukum normatif adalah penelitian hukum yang meletakkan hukum menjadi sebuah landasan norma. Sistem norma yang dimaksud adalah mengenai asas-asas, norma, kaidah dan peraturan perundangan-undangan, putusan pengadilan, perjanjian serta doktrin (ajaran). ${ }^{6}$

Dimana peneliti menggali bukti-bukti yang akurat dan sah tentang sebab suatu perkara yang menjadi objek penelitian. Penelitian ini juga dilaksanakan beserta membahas peraturan perundang-undangan yang berkaitan penelitian ini.

\section{Hasil dan Pembahasan.}

\subsection{Mekanisme Pembayaran Royalti atas Lagu Dan Musik dalam Aplikasi Streaming Musik kepada Pencipta}

1. Hak Cipta Lagu Dan Musik dalam Aplikasi Streaming Musik

Hak Cipta berisikan hak ekonomi (economic right) dan hak moral (moral right). Hak ekonomi adalah hak untuk mendapatkan manfaat ekonomi atas Ciptaan serta produk Hak terkait. Sedangkan hak moral adalah hak yang melekat pada diri Pencipta yang tidak dapat dihilangkan atau dihapus tanpa alasan apa pun, walaupun Hak Cipta atau Hak Terkait telah dialihkan. ${ }^{7}$

Pelanggaran terhadap Hak Cipta khususnya berupa pengumuman lagu dan/atau musik saat ini seolah-olah berlangsung tanpa adanya penyelasaian hukum yang berarti. Banyak dari masyarakat dalam kegiatan komersial menyiarkan musik atau lagu tanpa membayar royalti atau meminta izin dari Pencipta atau Pemegang Hak Ciptanya. Para Pencipta lagu memiliki hak untuk memberikan izin bagi para pengguna komersial dalam menggunakan karya ciptaannya untuk kepentingan komersial dan atas pemberian izin tersebut para Pencipta lagu berhak mendapatkan royalti.

Royalti merupakan inti dari Hak Ekonomi Pencipta dan Pemegang Hak Terkait. Adanya royalti menunjukkan penghargaan terhadap jerih payah dan talenta para Pencipta dan Pemegang Hak Terkait, sekaligus memberikan gairah (motivasi) kepada Pencipta dan Pemegang Hak Terkait untuk melahirkan ciptaan-ciptaan baru atau untuk berkarya. Tanpa royalti, tidak ada penghargaan yang patut kepada Pencipta dan Pemegang Hak Terkait. Akibatnya proses Penciptaan atau kreativitas akan terhenti. ${ }^{8}$

Oleh karena itu Pencipta atau Pemegang Hak Cipta harus mendapatkan perlindungan hukum. Menurut Hadjon, perlindungan hukum dibagi menjadi dua yaitu perlindungan hukum preventif dan perlindungan hukum represif. Perlindungan hukum preventif merupakan suatu bentuk perlindungan yang diberikan untuk mengajukan

\footnotetext{
${ }^{6}$ Mukti Fajar dan Yulianto Achmad, 2015, Dualisme Penelitian Hukum Empiris \& Normatif, Yogyakarta: Pustaka Pelajar.

${ }^{7}$ Rezky Lendi Maramis. 2014. Perlindungan Hukum Hak Cipta Atas Karya Musik dan Lagu dalam Hubungan dengan Pembayaran Royalti. Jurnal Lex Privatum. Vol II. No.2 hlm 118

${ }^{8}$ Bernard Nainggolan, 2011, Pemberdayaan Hukum Hak Cipta dan Lembaga Manajemen Kolektif, Bandung: Alumni, hlm. 164
} 
keberatan atas pendapat sebelum suatu keputusan pemerintah diberikan. Sedangkan perlindungan hukum represif diberikan setelah adanya aturan-aturan hukum yang dilanggar atau apabila seseorang merasa haknya telah dilanggar. ${ }^{9}$

Adapun perlindungan hukum preventif diberikan untuk mencegah terjadinya suatu pelanggaran terhadap suatu karya cipta khususnya dalam hal ini yaitu berupa lagu dan musik. Tindakan preventif yang dapat dilakukan ialah dengan cara melakukan pencatatan ciptaan seperti yang diatur dalam Pasal 66-67 Undang-Undang Hak Cipta. Ciptaan sudah dilindungi sejak ciptaan itu lahir sehingga tidak wajib untuk dicatatkan, tetapi fungsi pencatatan Hak Cipta dimaksudkan untuk memudahkan pembuktian dalam hal terjadi sengketa mengenai Hak Cipta.

Selanjutnya perlindungan represif, hal ini dilakukan setelah adanya suatu pelanggaran yang dilakukan atas suatu karya cipta milik Pencipta ini. Selain itu juga perlindungan ini diberikan untuk mencari suatu bentuk penyelesaian agar dapat mempertahankan hak-hak yang dimiliki Pencipta. Terkait dengan pelanggaran yang dilakukan yang dapat merugikan Pencipta tentu saja hal ini perlu untuk dihentikan dan memberikan sanksi maupun denda atas apa yang dilakukan terhadap karya cipta Pencipta tersebut.

Hukum Hak Cipta memberikan landasan bagi Pencipta dan Pemegang Hak Terkait agar bisa mempertahankan haknya. Akan tetapi di dalam Undang-Undang Hak Cipta tidak termuat aturan khusus tentang pengertian lagu atau musik, namun lagu atau musik adalah sebagai bagian dari karya yang dilindungi oleh Undang-Undang Hak Cipta sebagaimana terdapat dalam Pasal 40 ayat 1 Undang-Undang Hak Cipta. Berdasarkan Undang-Undang Hak Cipta No. 28 Tahun 2014, yang dimaksud "mengumumkan" adalah pembacaan, penyiaran, pameran, penjualan, pengedaran atau penyebaran suatu ciptaan dengan menggunakan alat apapun, termasuk media internet atau melakukan dengan cara apapun sehingga suatu ciptaan bisa dibaca, dilihat dan didengar.

Dapat disimpulkan bahwa pengertian mengumumkan ialah termasuk suatu kegiatan mengadaptasi, mengaransemen, menerjemahkan, menyanyikan ulang, menjual, mengalihwujudkan, meminjamkan, menyewakan, mengimpor, memamerkan mempertunjukkan kepada publik, menyiarkan, merekam dan mengomunikasikan suatu ciptaan kepada publik, melalui sarana apapun. Hal yang dimaksud diatas biasa dikenal dengan istilah performing right.

Pada saat ini, salah satu platform music streaming yang terbesar di dunia adalah Spotify. Spotify merupakan platform music streaming dimana untuk meng-upload (mengunggah) musik Anda memerlukan label atau pihak yang bermitra dengan Spotify. Hal ini dilakukan untuk meminimalisir pelanggaran Hak Cipta yang bisa saja terjadi, mengingat Spotify merupakan aplikasi streaming musik yang sudah ada di berbagai negara dunia. Menurut Informan Renno staff Digital Distribution of Euforia Digital

\footnotetext{
${ }^{9}$ Philipus M. Hadjon, 2005, Perlindungan Hukum Bagi Rakyat Indonesia, Surabaya: Bina Ilmu. hlm 2
} 
yang berwenang dalam pengelolaan dan pendistribusian musik menjelaskan bahwa Spotify berbeda dari beberapa aplikasi musik streaming musik lainnya seperti Soundcloud, Youtube dan lain sebagainya dalam hal mengupload musik atau lagu untuk kepentingan komersial. ${ }^{10}$

Spotify membuat kebijakan bagi para artis atau musisi yang menginginkan lagunya dimuat dalam aplikasi Spotify agar dapat memiliki label atau publisher terlebih dahulu. Secara sistem, seorang musisi dapat menjual lagunya pada aplikasi Spotify dengan cara sebagai berikut: ${ }^{11}$

Bagan 4. 1 Kebijakan upload lagu atau musik pada aplikasi Spotify.

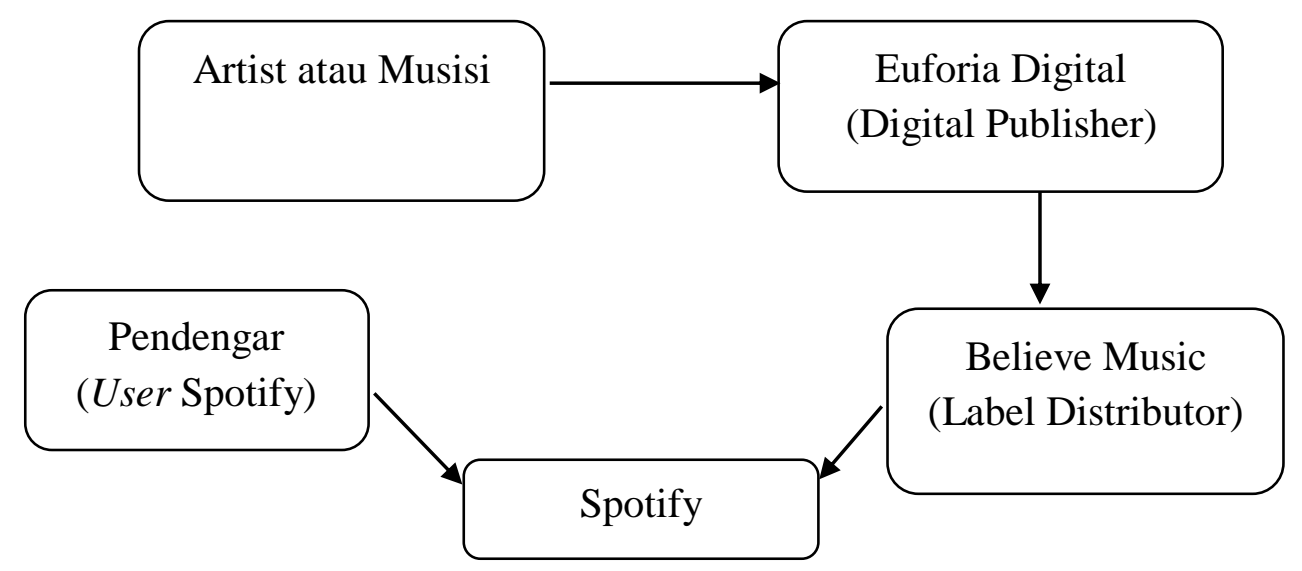

Sumber: Olahan peneliti Tahun 2019

Bagan 4.1 di atas menunjukan sebuah sistem yang dibangun oleh Spotify untuk meminimalisir potensi pelanggaran Hak Cipta yang dilakukan oleh para musisi. Pada bagan tersebut seorang musisi atau artis yang ingin menjual lagunya diwajibkan untuk memiliki label atau publisher yang bertugas dan memiliki hak atas lisensi sebuah Hak Cipta. Spotify sendiri memiliki beberapa label distribusi yang bekerjasama dalam pengelolaan Hak Cipta musik sebelum dapat dimasukkan dalam daftar putar musik aplikasi. Beberapa diantaranya adalah Believe Music, Absolute Label Service, dan DANMARK. Di Indonesia sendiri Spotify belum memiliki label atau publisher yang secara langsung bekerjasama dengannya, sehingga untuk memasukkan lagu kedalam Spotify para musisi terlebih dahulu harus memiliki label atau publisher di Indonesia yang berwenang untuk mengelola Hak Cipta atas lagu atau musik dan kemudian pihak label atau publisher yang ada di Indonesia akan mengajukan permintaan kepada label atau publisher yang telah ditentukan oleh Spotify. Hal ini dilakukan untuk memberikan perlindungan secara hukum terhadap para Pencipta atau Pemegang Hak Cipta.

\footnotetext{
${ }^{10}$ Renno Ferthano, 2019, "Pembahasan Mengenai Era Distribusi Musik Digital”. Hasil Wawancara Pribadi, Kantor Euforia Music Publisher.

${ }^{11}$ Spotify, 2019, Syarat dan Ketentuan Pengguna Spotify, https://www.Spotify.com/id/legal/end-useragreement/\#s23, di akses pada tanggal 3 Desember 2019 pukul 20.39 WIB
} 
Dilihat dari hak dan kewajiban masing-masing pihak yang terdapat pada Bagan 4.1 dapat dijelaskan sebagai berikut: ${ }^{12}$

1. Pendengar / User Spotify memiliki hak untuk mendengarkan lagu atau musik yang dia inginkan dengan kualitas yang baik dan berkewajiban untuk melakukan pembayaran royalti dalam menggunakan atau mendengar lagu yang terdapat pada aplikasi Spotify. Tetapi ada juga pendengar yang dapat mendengar musik secara gratis hanya saja disela musik atau pergantian musik pengguna gratis akan melihat iklan yang muncul.

2. Spotify berhak mendapatkan dan mengelola hak cipta atas karya cipta secara komersil baik pembayaran dari para pendengar premium maupun pengiklan yang akan dimunculkan bagi pengguna gratis. Sedangkan kewajiban Spotify adalah mengeluarkan atau memberikan royalti yang didistribusikan kepada label distributor terlebih dahulu sebelum diserahkan kepada Pencipta atau Pemegang Hak Cipta. Hal ini tertuang dalam syarat dan ketentuan saat pencipta lagu atau publisher ingin mendistribusikan karya cipta melalui aplikasi Spotify.

3. Label Distributor yang bekerjasama langsung dengan Spotify seperti halnya Believe Music memiliki kewajiban dalam mendistribusikan royalti kepada label artis atau Digital Publisher. Dilain sisi Label Distributor berhak mendapatkan fee distribusi yang besarannya telah disepakati pada awal perjanjian.

4. Digital Publisher memiliki kewajiban untuk mendistribusikan atau memasarkan setiap lagu atau musik yang pengelolaan hak nya diberikan artis kepada Digital Publisher. Oleh karena itu Digital Publisher memiliki hak pembagian fee terhadap royalti yang dihasilkan dalam penjualan lagu atau musik. Sama halnya dengan label distributor besaran fee yang diberikan sesuai kesepakatan atau perjanjian yang disepakati antara artis dan Digital Publisher.

5. Artis atau musisi memiliki kewajiban untuk membuat sebuah karya yang kemudian akan dikelola atau dipasarkan oleh Digital Publisher. Sedangkan hak seorang artis atau musisi adalah menerima royalti atas karya yang dimilikinya sebagai Pencipta dan/atau Pemegang Hak Cipta. Besaran royalti yang diterima oleh artis tergantung kesepakatan yang dibuat bersama Digital Publisher.

Salah satu aplikasi file sharing musik populer lainnya adalah Soundcloud. Situs berbagi audio Soundcloud dalam laman kebijakan Hak Cipta nya menghimbau agar pembuatan dan pengunggahan cover song sebaiknya disertai izin atau lisensi yang sesuai jika hendak mempublikasikannya. Hal ini dihimbau dikarenakan sebagian produsen dan penerbit baik-baik saja dengan pihak ketiga menggunakan materi mereka, namun beberapa yang lain tidak dan tidak ingin karya mereka digunakan tanpa persetujuan eksplisit.

\footnotetext{
${ }^{12}$ Renno Ferthano, 2019, "Pembahasan Mengenai Era Distribusi Musik Digital”. Hasil Wawancara Pribadi, Kantor Euforia Music Publisher.
} 
Pada praktiknya pemilik Hak Cipta dapat melindungi karya cipta mereka pada pilihan lisensi yang disediakan Soundcloud, dengan memilih All Rights Reserved dan Creative Commons. Apabila memilih All Rights Reserved, ciptaan yang diunggah dilindungi oleh Hak Cipta konvensional, yaitu setiap orang harus meminta izin secara langsung kepada Pencipta atau Pemegang Hak Cipta untuk melakukan segala bentuk tindakan terhadap ciptaan tersebut. Segala bentuk tindakan yang dimaksud termasuk tindakan membuat salinan, membuat ciptaan turunan (mengubah), sampai dengan mendapatkan keuntungan komersial (menjual). ${ }^{13}$

Apabila Pencipta atau Pemegang Hak Cipta memilih Creative Commons, maka Pencipta atau Pemegang Hak Cipta memilih untuk menyebarluaskan ciptaan dengan lisensi Creative Commons. Lisensi Creative Commons adalah bentuk alternatif perjanjian Hak Cipta, sehingga bukanlah bentuk pelepasan Hak Cipta. lisensi Creative Commons diimplementasikan di Indonesia berdasarkan Pasal 80 UUHC, sehingga keberlakuannya memang mengacu pada Undang-Undang Hak Cipta yang berlaku.

Serupa dengan Youtube dan Soundcloud yang secara teknis menerapkan hal yang sama untuk melindungi karya cipta Pencipta atau Pemegang Hak Cipta yang digunakan sebagai cover song. Spotify telah menggunakan sistem identifikasi konten otomatis. Sistem tersebut bekerja layaknya seperti yang digunakan oleh Youtube, ketika pengguna mengunggah lagu, secara otomatis sistem tersebut memeriksa unggahan pengguna terhadap basis data trek yang diminta oleh pemilik Hak Cipta. Jika sistem mendeteksi kecocokan, maka unggahan pengguna tersebut bisa saja diblokir atau akan dihapus secara otomatis apabila Pencipta atau Pemegang Hak Cipta keberatan. ${ }^{14}$

2. Pembayaran Royalti Lagu Dan Musik dalam Aplikasi Streaming Musik

Dalam Undang-Undang Nomor 28 Tahun 2014 Hak Cipta merupakan hak khusus bagi Pencipta atau Pemegang Hak Cipta untuk memperbanyak atau menggandakan dan untuk mengumumkan hasil karya ciptaannya yang tumbuh bersamaan dengan lahirnya suatu ciptaan. Pencipta berhak pula atas manfaat ekonomi yang lahir dari ciptaanya tersebut. Manfaat ekonomi tersebut dapat bersumber dari kegiatan mengumumkan (performing right), kegiatan menyiarkan (broadcasting right), kegiatan memperbanyak yang mana termasuk didalamnya; mechanical, printing, syncronization, advertising, dan kegiatan menyebarkan (distribution right). ${ }^{15}$ Hal tersebut dapat dilakukan dengan mengadakan rekaman bersama produser musik yang kemudian akan diperbanyak melalui CD/DVD dan melakukan perform di radio-radio,

\footnotetext{
${ }^{13}$ Soundcloud, 2019, Choosing License for Your Track, https://help. soundcloud.com/hc/enus/articles/115003566468-Choosing-a-license-for-your-track, diakses pada tanggal 7 April 2019 pukul 11.05 WIB

${ }^{14}$ Ghaesany Fadhila, U.Sudjana. 2018. "Perlindungan Karya Cipta Lagu atau Musik yang Dinyanyikan Ulang (Cover Song) Di Jejaring Media Sosial dikaitkan dengan Hak Ekonomi berdasarkan UndangUndang No 28 Tahun 2014 tentang Hak Cipta”. Jurnal Hukum Kenotariatan dan Ke-PPAT-an. Vol 1. No 2. Hal. 121

${ }^{15}$ Hendra Tanu Atmadja, 2003. Hak Cipta Musik atau Lagu, Jakarta: Penerbit Pasca Sarjana Universitas Indonesia. hlm 299
} 
televisi atau juga dapat melakukannya dengan mengunggahnya ke aplikasi musik streaming seperti Spotify, Joox, Soundcloud, dan lainnya sehingga masyarakat akan tertarik.

Adapun mekanisme pembayaran royalti terkait bagi hasil pendapatan bagi musik yang diunggah di Spotify dan telah diklaim oleh Pencipta/penerbit musik adalah dengan cara: ${ }^{16}$

Bagan 4. 1 Mekanisme Pembayaran Royalti Spotify

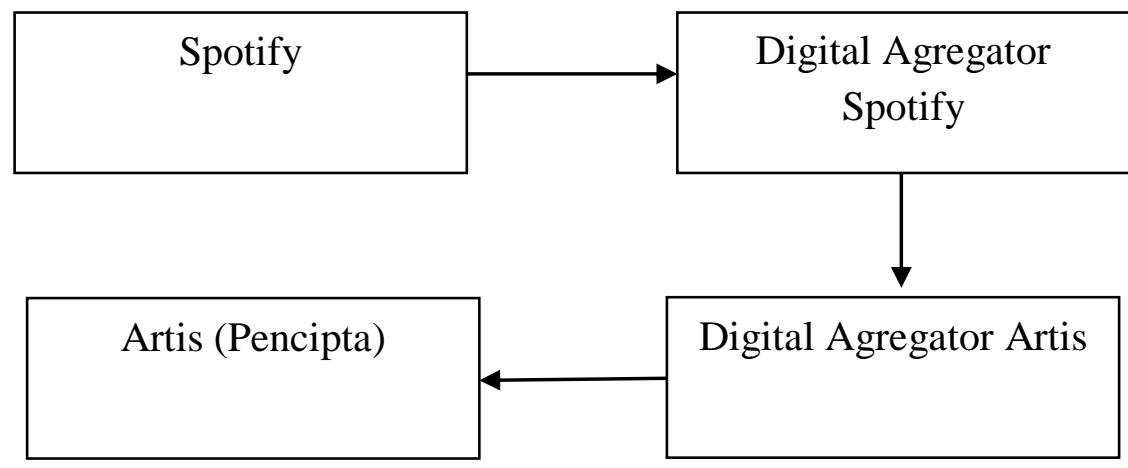

Sumber: Olahan Peneliti Pada Tahun 2019

Bagan 4.2 di atas merupakan proses pembayaran royalti yang dilakukan oleh Spotify kepada Pencipta atau Pemegang Hak Cipta. Adapun penjelasan dari masingmasing tahapan tersebut sebagai berikut: ${ }^{17}$

1. Proses pemberian royalti berupa bagi hasil akan dibayarkan kepada pihak musisi atau penyanyi yang telah mendaftarkan akunnya di Spotify, sistem pencairan royalti bagi hasil dilakukan dengan tahapan Spotify akan memberikan royalti dan laporan royalti kepada digital aggregator atau yang disebut dengan pembeli lisensi Hak Cipta yang bekerja sama dengan Spotify terlebih dahulu.

2. Adapun besaran royalti yang diberikan oleh Spotify terhadap para musisi berbedabeda. Pada umumnya akan ditentukan berdasarkan pertimbangan pendapatan perkapita negara tertentu. Misalnya di Indonesia, royalti yang diberikan oleh Spotify dalam setiap 1x stream video yaitu sebesar 0,004533 euro. Pembayaran ini akan dilakukan setiap bulannya selama lagu tersebut terdaftar dan memiliki pemutaran pada aplikasi Spotify.

3. Selanjutnya, digital aggregator akan memberikan royalti yang telah dipotong client share rate sebesar 0,7 dari total penghasilan royalti berdasarkan kesepakatan yang telah disetujui antara digital aggregator Spotify dan digital aggregator artis. Pembayaran dilakukan pertiga bulan oleh digital aggregator dikarenakan

\footnotetext{
${ }^{16}$ Renno Ferthano, 2019, "Pembahasan Mengenai Era Distribusi Musik Digital”. Hasil Wawancara Pribadi, Kantor Euforia Music Publisher.

${ }^{17}$ Renno Ferthano, 2019, "Pembahasan Mengenai Era Distribusi Musik Digital". Hasil Wawancara Pribadi, Kantor Euforia Music Publisher.
} 
pertimbangan besaran nominal mengingat tidak semua artis yang bekerja sama merupakan artis yang terkenal.

4. Royalti yang telah diberikan kepada digital aggregator artis selanjutnya akan dibagi kepada artis atau musisi (Pencipta). Pembagian antara digital aggregator artis dan artis juga mengikuti kesepakatan perjanjian awal. Sebagai contoh Euforia Music Publisher sebagai induk perusahaan dari Digital Euforia yang menjadi narasumber dalam penelitian ini memberikan royalti sebesar 70\% kepada musisi dari total royalti yang dikumpulkan. Pembayaran dilakukan setiap tiga bulan sekali dalam satu tahun.

Berdasarkan penjelasan di atas dapat dilihat penting bagi seorang musisi atau Pemegang Hak Cipta untuk memiliki label distributor atau Digital Publisher agar dapat memudahkan dalam mengekploitasi Hak Ciptanya dalam bentuk komersil. Hal ini dikarenakan media internet yang tidak memiliki batas wilayah akan sulit bagi Pencipta untuk mengawasi pengumuman karya ciptaanya. Selain itu kebijakan yang ditetapkan oleh platform aplikasi musik streaming yang menuntut agar artis atau pencipta memiliki Digital Publisher untuk meminimalisir pelanggaraan Hak Cipta. Pengalihan hak ekonomi suatu ciptaan biasanya dilakukan berdasarkan kesepakatan bersama yang dituangkan dalam perjanjian. Ada dua cara pengalihan ekonomi tersebut dalam praktik, yaitu:

a. Pengalihan hak eksploitasi/hak ekonomi dari Pencipta kepada Pemegang Hak Cipta dengan memberikan izin berdasarkan suatu perjanjian yang mencantumkan hak-hak Pemegang Hak Cipta dalam jangka waktu tertentu untuk melakukan perbuatanperbuatan tertentu dalam kerangka eksploitasi ciptaan yang Hak Ciptanya tetap dimiliki oleh Pencipta. Untuk pengalihan hak eksploitasi ini Pencipta memperoleh suatu jumlah tertentu sebagai imbalannya.

b. Pengalihan Hak Ekonomi secara assignment (penyerahan). Dengan perkataan lain, Pencipta menyerahkan seluruh Hak Ciptanya dengan cara penyerahan. Hak Cipta yang dijual untuk seluruhnya atau sebagiannya, tidak dapat dijual untuk kedua kali oleh penjual yang sama.

Pada praktiknya lingkup perjanjian lisensi Hak Cipta meliputi semua perbuatan untuk mengumumkan atau memperbanyak ciptaan dengan kewajiban memberikan royalti kepada Pencipta atau Pemegang Hak Cipta oleh penerima lisensi berdasarkan kesepakatan kedua belah pihak dan berlangsung selama jangka waktu lisensi diberikan dan berlaku untuk seluruh wilayah Republik Indonesia. Pemegang Hak Cipta tetap boleh melaksanakan sendiri atau memberikan lisensi kepada pihak ketiga untuk mengumumkan atau memperbanyak ciptaannya, agar dapat mempunyai akibat hukum terhadap tuntutan pihak ketiga, perjanjian lisensi wajib dicatatkan sesuai dengan ketentuan Pasal 83 ayat (1) yang mengatur bahwa, Perjanjian Lisensi harus dicatatkan oleh Mentri dalam daftar umum perjanjian Lisensi Hak Cipta dengan dikenai biaya. Selanjutnya diatur pula dalam Pasal 83 ayat (3) jika perjanjian Lisensi tidak dicatat 
dalam daftar umum sebagaimana dimaksud pada ayat (1), maka perjanjian Lisensi tersebut tidak mempunyai akibat hukum terhadap pihak ketiga.

Perjanjian Lisensi sebagai perjanjian tertulis pengalihan Hak Cipta, bukan hanya berdasarkan Undang-Undang No. 28 Tahun 2014 tentang Hak Cipta saja melainkan juga harus berdasarkan ketentuan-ketentuan mengenai syarat-syarat sah nya suatu perjanjian sesuai yang di atur dalam KUHPerdata. Tahap awal perjanjian Lisensi disepakati dan ditandatangani hingga tahap pelaksanaan perjanjian, melalui beberapa proses seperti mengenai syarat sahnya perjanjian, yang di atur dalam Pasal 1320 KUHPerdata yang mengatur bahwa, untuk sahnya suatu perjanjian diperlukan empat syarat:

a. Adanya kesepakatan kehendak;

Yang dimaksud dengan kesepakatan ialah persetujuan secara bebas dari pihakpihak yang mengadakan perjanjian. Kehendak satu pihak haruslah juga kehendak pihak yang lain. Kesepakatan harus diberikan dalam keadaan sadar, bebas (tidak dalam tekanan) dan bertanggungjawab.

b. Kecakapan untuk membuat suatu perikatan;

Adanya kecakapan atau kemampuan untuk membuat perjanjian. yang dimaksud dengan kecakapan ialah memiliki pengetahuan dan kehendak terhadap hal yang diperjanjikan serta dianggap mampu mempertanggung jawabkan apa yang diperjanjikannya. Pada dasarnya setiap orang yang sudah dewasa dan berakal sehat mampu mengetahui dan menghendaki apa yang diperjanjikan.

c. Suatu hal tertentu;

Adanya suatu hal tertentu yang diperjanjikan. Objek perjanjian harus jelas, apabila berupa barang maka harus jenis-jenis, jumlah, dan harganya. Paling tidak dari keterangan mengenai obyek, harus dapat ditetapkan apa yang menjadi hak dan kewajiban masing masing pihak.

d. Suatu sebab yang halal.

Adanya suatu sebab yang halal (tidak dilarang oleh Undang-Undang). Maksudnya adalah isi perjanjian tidak boleh bertentangan dengan perundang-undangan yang bersifat memaksa, ketertiban umum, dan kesusilaan.

Berkenaan dengan perjanjian Lisensi atas karya cipta lagu dalam hubungan kerja Pencipta lagu dan produser rekaman suara ada kesepakatan-kesepakatan yang kemudian dituangkan dalam suatu surat perjanjian. Ada empat macam bentuk perjanjian antara Pencipta lagu dengan produser rekaman suara berdasarkan pembayaran honorarium Pencipta lagu, yaitu: ${ }^{18}$

a. Flat pay sempurna atau jual putus;

\footnotetext{
${ }^{18}$ Otto Hasibuan, 2008, Hak Cipta di Indonesia Tinjauan Khusus Hak Cipta Lagu, Neighbouring Rights, dan Collecting Society, Bandung: PT. Alumni, HIm 169
} 
b. Flat pay terbatas atau bersyarat;

c. Royalti; dan

d. Semi Royalti.

Akan tetapi, materi atau isi muatan yang ada dalam perjanjian lisensi merupakan kebebasan para pihak dalam menentukan isi perjanjian. Isi perjanjian lisensi merupakan kebebasan berkontrak bagi para pihak yang melakukan perjanjian lisensi. Dalam arti bahwa, perjanjian dalam kebebasan berkontrak adalah mencerminkan kedudukan yang sama bagi para pihak. Doktrin kebebasan berkontrak (freedom of contract) dapat diartikan sebagai suatu keadaan hukum dimana para pihak menentukan sendiri isi perjanjian atau kesepakatan dalam kontrak. Sumber dari kebebasan berkontrak adalah kebebasan individu sehingga titik tolaknya adalah kepentingan individu. Dengan demikian, dapat dipahami bahwa kebebasan individu memberikan kepadanya kebebasan untuk berkontrak. Berlakunya asas konsensualisme menurut hukum perjanjian yang memberi pengertian bahwa perjanjian sudah terjadi dan bersifat mengikat sejak tercapai kesepakatan (konsensus) antara kedua belah pihak mengenai objek perjanjian. Disini telah dapat ditetapkan apa yang menjadi hak dan kewajiban dari masing-masing pihak.

\section{Simpulan}

\subsection{Simpulan}

a. Berdasarkan hasil penelitian dan pembahasan di atas mengenai mekanisme pembayaran royalti lagu dan musik dalam aplikasi streaming musik, dapat disimpulkan bahwa:

b. Mekanisme pembayaran royalti atas lagu dan musik dalam aplikasi streaming musik kepada pencipta akan didistribusikan melalui beberapa tahapan yang dimulai dari penyedia layanan musik streaming dalam hal ini Spotify kepada label distributor, selanjutnya dari label distributor kepada Digital Publisher dan terakhir dari Digital Publisher kepada musisi atau artis selaku Pencipta atau Pemegang Hak Cipta.

\subsection{Saran}

a. Bahwa perlunya ada kesadaran dari masyarakat khususnya para pemakai Hak Cipta agar lebih memperhatikan lagu dan/atau musik yang digunakan secara komersil dengan membayarkan royalti pada Pencipta atau Pemegang Hak Cipta lagu dan/atau musik tersebut.

b. Pemerintah harus lebih tegas dalam memusyawarahkan Undang-Undang Hak Cipta kepada masyarakat, mengingat masih banyaknya terjadi pelanggaran Hak Cipta dan pemerintah harus membuat peraturan khusus mengenai perlindungan hukum terhadap karya cipta lagu dan/atau musik. 


\section{Daftar Pustaka}

\section{Buku}

Bernard Nainggolan. (2011). Pemberdayaan Hukum Hak Cipta dan Lembaga Manajemen Kolektif. Bandung: PT. Alumni.

Philipus M. Hadjon. (2005). Perlindungan Hukum Bagi Rakyat Indonesia. Surabaya: Bina Ilmu.

Hendra Tanu Atmadja. (2003). Hak Cipta Musik atau Lagu. Jakarta: Penerbit Pasca Sarjana Universitas Indonesia.

Mukti Fajar dan Yulianto Achmad. (2015). Dualisme Penelitian Hukum Empiris \& Normatif. Yogyakarta: Pustaka Pelajar.

Otto Hasibuan. (2008). Hak Cipta di Indonesia Tinjauan Khusus Hak Cipta Lagu, Neighbouring Rights, dan Collecting Society. Bandung: PT. Alumni.

\section{Jurnal}

Ghaesany Fadhila, U. Sudjana. (2018). "Perlindungan Karya Cipta Lagu atau Musik yang Dinyanyikan Ulang (Cover Song) Di Jejaring Media Sosial dikaitkan dengan Hak Ekonomi berdasarkan Undang-Undang No 28 Tahun 2014 tentang Hak Cipta”. Jurnal Hukum Kenotariatan dan Ke-PPAT-an. Vol 1. No 2. Hal. 121-235

Rezky Lendi Maramis. (2014). "Perlindungan Hukum Hak Cipta Atas Karya Musik dan Lagu dalam Hubungan dengan Pembayaran Royalti”. Jurnal Lex Privatum. Vol. 2. No. 2 Hal. 116-125.

\section{Regulasi}

Undang-Undang Nomor 28 Tahun 2014 Tentang Hak Cipta

Kitab Undang-Undang Hukum Perdata

\section{Internet}

Anita Wardani. (2017). "Vokalis Payung Teduh Kecewa dengan Hanin Dhiya Gara-gara Cover Lagu Akad". https://www.tribunnews.com/seleb/2017/10/03/vokalispayung-teduh-kecewa-dengan-hanin-dhiya-gara-gara-cover-lagu-akad, di akses pada tanggal 3 Desember 2019 pukul 20.59 WIB

Deliusno. (2016). "Spotify Masuk, Total Ada 8 Layanan "Streaming” Musik di Indonesia”.https://tekno.kompas.com/read/2016/03/31/13140017/Spotify.Masuk. Total.Ada.8.Layanan.Streaming.Musik.di.Indonesia?page=all, di akses pada tanggal 13 Oktober 2019 pukul 10.04 WIB

Karya Cipta Indonesia. (2018). "Karya Cipta Indonesia (KCI) adalah Lembaga Manajemen Kolektif (LMK) hak cipta lagu". http://kci-lmk.or.id/, di akses pada tanggal 8 April 2019 pukul 10.43 WIB 
Kustin Ayuwuragil. (2018). "Spotify Dituntut Triliunan Rupiah Oleh Label Musik,". https://www.cnnindonesia.com/teknologi/20180103152623-185-266437/Spotifydituntut-triliunan-rupiah-oleh-label-musik, di akses pada tanggal 8 April 2019 pukul 20.09 WIB

Mochamad Wahyu Hidayat. (2015). "Dianggap Curangi Artis, Spotify Dituntut US\$ 150 Juta". https://www.liputan6.com/tekno/read/2400645/dianggap-curangiartis-Spotify-dituntut-us-150-juta, di akses pada tanggal 8 April 2019 pukul 20.00 WIB

Soundcloud. (2019). "Choosing License for Your Track". https://help. soundcloud.com/hc/en-us/articles/115003566468-Choosing-a-license-for-yourtrack,_diakses pada tanggal 7 April 2019 pukul 11.05 WIB

Spotify. (2019). "Syarat dan Ketentuan Pengguna Spotify". https://www.Spotify.com/id/legal/end-user-agreement/\#s23, di akses pada tanggal 3 Desember 2019 pukul 20.39 WIB

\section{Wawancara}

Renno Ferthano. (2019). "Pembahasan Mengenai Era Distribusi Musik Digital”. Hasil Wawancara Pribadi. Kantor Euforia Music Publisher. 